\title{
Dispersive Liquid-Liquid Microextraction of Lead(II) as Tropaeolin 000 Chelates From Environmental Samples Prior to Microsampling Flame Atomic Absorption Spectrometry
}

\author{
M.A. Habila ${ }^{\text {a }}$ Z.A. ALOthman ${ }^{\text {a }}$, E. Yilmaz ${ }^{\text {b }}$, M. Soylak,,* \\ ${ }^{a}$ Chemistry Department, College of Science, King Saud University, Riyadh-11451, Kingdom of Saudi Arabia \\ ${ }^{b}$ Erciyes University, Faculty of Sciences, Department of Chemistry, 38039, Kayseri, Turkey
}

\section{INTRODUCTION}

The widespread presence of lead in the environment poses a high risk to human health. Lead can be absorbed and enter the human body by inhalation, drinking water and eating foods, or through skin contact with dust. High levels of exposure to lead can cause anemia, even death. Low exposure to lead can affect the immune system, the reproductive and nervous systems, and brain injury (1-4). Therefore, the determination and remediation of lead is important to ensure safe environmental conditions (5). However, the determination of low levels of lead in some samples is still a problem because of the detection range of the analytical instruments.

Flame atomic absorption spectrometry, graphite furnace atomic absorption spectrometry, and inductively coupled plasma atomic emission spectrometry have been used for the accurate determination of lead in environmental samples. However, to reduce matrix effects as well as to enrich the analyte in case of trace levels, preconcentration and separation of the analytes becomes necessary (6). For this purpose, various separation and preconcentration procedures including solid phase extraction (7) and dispersive liquid-liquid microextraction (DLLME) (8) have been applied. DLLME exhibits advantages such as fast interaction and separation as well as requiring less solvents (9).

\footnotetext{
${ }^{*}$ Corresponding author.

E-mail: soylak@erciyes.edu.tr

Fax: +90 3524374933
}

\begin{abstract}
In the present work, lead(II) at trace level was extracted by a dispersive liquid-liquid microextraction procedure. The process was followed by flame atomic absorption spectrometry (FAAS) for trace determination of lead. Tropaeolin OOO was used as the chelating agent for lead(II). The analytical conditions for the quantitative recoveries of lead(II) were investigated. Lead (II) - Tropaeolin OOO chelate was quantitatively extracted to $200 \mu \mathrm{L}$ of $\mathrm{CCl}_{4}$ at $\mathrm{pH} 4$. The limit of detection (LOD) was $11.4 \mu \mathrm{g} \mathrm{L}^{-1}$. The recovery tests from the certified reference materials TMDA 64.2 and TMDA 53.3 Water Samples were in good agreement. The microextraction procedure showed applicability to wastewater and hair samples obtained from Kayseri, Turkey.
\end{abstract}

Various reports have been published that focus on improving liquid liquid microextraction efficiency (10). ALOthman et al. (11) developed a temperature-assisted ionic liquid-based microextraction procedure for lead(II) and reported a detection limit of $5.8 \mu \mathrm{g} \mathrm{L}^{-1}$. Baig et al. (12) developed ultrasonic enhanced dispersive liquid-liquid microextraction and combined a microsample injection system with flame atomic absorption spectrometry (MIS-FAAS). Lopez-Garcia et al. (13) determined trace concentrations of lead in environmental samples by applying ionic liquid modified dispersive liquid-liquid microextraction prior to electrothermal atomic absorption spectrometry analysis. This process leads to the formation of fine droplets which allows dispersion of organic solvents and resulted in detection limits of $3 \mathrm{ng} \mathrm{L}^{-1}$ for lead. Furthermore, Lopez-Garcia et al. (14) applied the dispersive liquidliquid microextraction procedure directly to edible oils with isopropyl alcohol for the determination of lead with a detection limit of 10 ng kg-1 for lead. Jalbani and Soylak (15) developed a microextraction procedure for the determination of lead by FAAS after solid liquidsolid dispersive extraction, followed by ionic liquid-based dispersive liquid-liquid microextraction.

In this work, a dispersive liquidliquid microextraction procedure has been established for the determination of trace levels of $\mathrm{Pb}$ (II) in environmental samples. Tropaeolin OOO was used as the chelating agent for the quantitative extraction of $\mathrm{Pb}$ (II). After microextraction, the lead contents were determined using microsampling flame atomic absorption spectrometry.

\section{EXPERIMENTAL}

\section{Instrumentation}

A 3110 flame atomic absorption spectrometer (PerkinElmer, Inc., Shelton, CT, USA), equipped with a hollow cathode lamp, was used for lead detection with the instrumental parameters listed in Table I. The calibration curve equation for lead was $(\mathrm{A}=0.013 \mathrm{C}(\mathrm{Pb})+$ 0.001 ), where $A$ is the absorbance and $\mathrm{C}$ is the concentration of the 
analyte. The correlation coefficient of the equation was 0.9995 .

The $\mathrm{pH}$ optimization was achieved using a PT-10 pH meter (Sartorius, Germany). An ALC PK 120 entrifuge was used for centrifugation of the solutions. A vortex mixer (VWR International LLC, USA) and a Soronex DT-255 ultrasonic bath (Bandelin Co., Germany) were also used for this study.

\section{Reagents and Standard Solutions}

All chemicals used were of analytical reagent grade. A stock $\mathrm{Pb}$ (II) solution (1000 $\mathrm{mg} \mathrm{L}^{-1}$ ) was prepared with lead nitrate. A $0.1 \mathrm{~g}$ Tropaeoline OOO (No. 75360-25G, Fluka, Switzerland) was dissolved in $30 \mathrm{~mL}$ of distilled water (Milli-Q ${ }^{\circledR}$ system, Millipore Corporation, USA) and $1 \mathrm{~mL}$ of $0.1 \mathrm{HCl}$ was added, then completed to $100 \mathrm{~mL}$ with distilled water. $\mathrm{NaOH}$ and $\mathrm{HCl}$ were used (Merck, Germany) and the buffer solutions were prepared according to the literature $(16,17)$.

\section{Test Procedure}

$\mathrm{A} \mathrm{Pb}$ (II) aqueous solution was placed into a 50-mL test tube and the $\mathrm{pH}$ of the solution maintained at $\mathrm{pH} 4$ using the phosphate buffer. Then, $100 \mu \mathrm{L}$ of Tropaeolin OOO, $1.0 \mathrm{~mL}$ of ethanol and $200 \mu \mathrm{L}$ of $\mathrm{CCl}_{4}$ were added to enhance phase separation. The mixture was vigorously vortexed for one minute. Phase separation of the aqueous phase from the organic phase was achieved by centrifugattion for 10 minutes at $4000 \mathrm{rpm}$. The aqueous phase was easily decanted with a pipette. The organic phase was dissolved in $\mathrm{HNO}_{3}$, brought to $500-\mu \mathrm{L}$ volume with distilled water, then $25 \mu \mathrm{L}$ was injected into the flame atomic absorption spectrometer by using the micro-injection method (16-19).

\section{Application of the Method to CRMs and Real Water Samples}

The proposed method was applied to certified reference materials (CRM) TMDA 64.2 Water and TMDA 53.3 Water (National Water Research Institute, Environment Canada, Burlington, Canada) including various water samples and hair samples. The water samples (tap water, wastewater, dam water, and river water) were immediately filtered through a $0.45 \mu \mathrm{m}$ pore size membrane filter. Then $15 \mathrm{~mL}$ from each sample was analyzed for $\mathrm{Pb}$ concentration using the procedure described above.

In addition, a $1.0 \mathrm{~g}$ hair sample was placed into a $100-\mathrm{mL}$ beaker, digested in concentrated nitric acid $(65 \% \mathrm{w} / \mathrm{w})$, and $10 \mathrm{~mL}$ distilled water was added (20). For $\mathrm{Pb}$ analysis, the microextraction procedure described above was applied.

\section{RESULTS AND DISCUSSION}

Selection of Optimum Analytical Conditions for the Microextraction Procedure

For quantitative recoveries of the analytes in the extraction studies, the $\mathrm{pH}$ is an important parameter (21-27). For the present microextraction study, the recoveries were investigated in the $\mathrm{pH}$ range of 2.0-8.0. The results in Figure 1 show that the recoveries of $\mathrm{Pb}(\mathrm{II})$ were quantitative at $\mathrm{pH} 4.0$ which was selected as optimal $\mathrm{pH}$ for further studies.

TABLE I

Conditions for Flame Atomic Absorption Spectrometry

\begin{tabular}{|c|c|c|c|c|}
\hline Element & $\begin{array}{l}\text { Wavelength } \\
\qquad(\mathrm{nm})\end{array}$ & $\begin{array}{l}\text { Slit Width } \\
\text { (nm) }\end{array}$ & $\underset{(\mathrm{mA})}{\operatorname{Lamp} \text { Current }}$ & $\begin{array}{l}\text { Flame Conditions* } \\
\begin{array}{lll}\text { (a) } & \text { (b) }\end{array}\end{array}$ \\
\hline $\mathrm{Pb}$ & 283.3 & 0.7 & 15 & 2.3 \\
\hline
\end{tabular}

* (a) Air (L/min), (b) Acetylene (L/min).

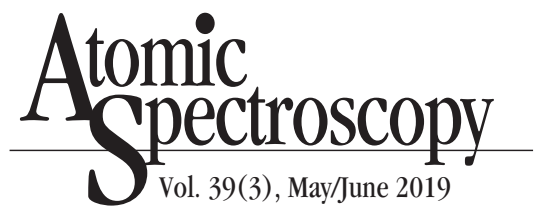

For the selection of a suitable chelating agent it is important to convert metal ions into the organometallic structure for quantitative recovery (28-32). In the present study, $0.1 \%$ of Tropaeolin OOO (Acid Orange 20) as sodium 4-((2E)-2-(4-oxonaphthalen-1-ylidene) hydrazinyl)benzenesulfonate was used and the influence of volume optimized in the range of $0-300 \mu \mathrm{L}$ at $\mathrm{pH}$ 4.0. Figure 2 shows that quantitative recoveries of $\mathrm{Pb}$ (II) were obtained with $100 \mu \mathrm{L}$ of $0.1 \%$ (w/v) Tropaeolin OOO solution.

In order to select a suitable dispersing agent for the quantitative recovery of $\mathrm{Pb}$ (II), $1000 \mu \mathrm{L}$ of a different solvent was used (see Figure 3). It was found that $1000 \mu \mathrm{L}$ of ethanol as the dispersing agent provided best results and was used for further work.

The effect of volume of carbon tetrachloride as extraction solvent was optimized in the range of 0-300 $\mu \mathrm{L}$. Figure 4 shows that 200 $\mu \mathrm{L}$. of carbon tetrachloride provides best quantitative recoveries for $\mathrm{Pb}$ (II).

The effect of sample volume on the recoveries was also investigated by using model solutions. Quantitative recoveries were obtained up to $15 \mathrm{~mL}$ of sample solution. The preconcentration factor was 30 when the sample volume and final volume were $15 \mathrm{~mL}$ and $0.5 \mathrm{~mL}$, respectively.

\section{Tolerance of Coexisting Ions}

The presence of matrix or other coexisting ions in environmental samples usually affects the preconcentration-separation procedures (33-37). Thus, model solutions of commonly existing ions in environmental samples were prepared individually, and their effect on the recovery was investigated. As shown in Table II, the recoveries are quantitative in the presence of most matrixes tested $\left(\mathrm{F}^{-}, \mathrm{Co}^{2+}, \mathrm{Ni}^{2+}\right.$, $\mathrm{Cd}^{2+}, \mathrm{Fe}^{2+}, \mathrm{Zn}^{2+}, \mathrm{Cu}^{2+}, \mathrm{K}^{+}, \mathrm{Cl}^{-}, \mathrm{Mg}^{2+}$, 


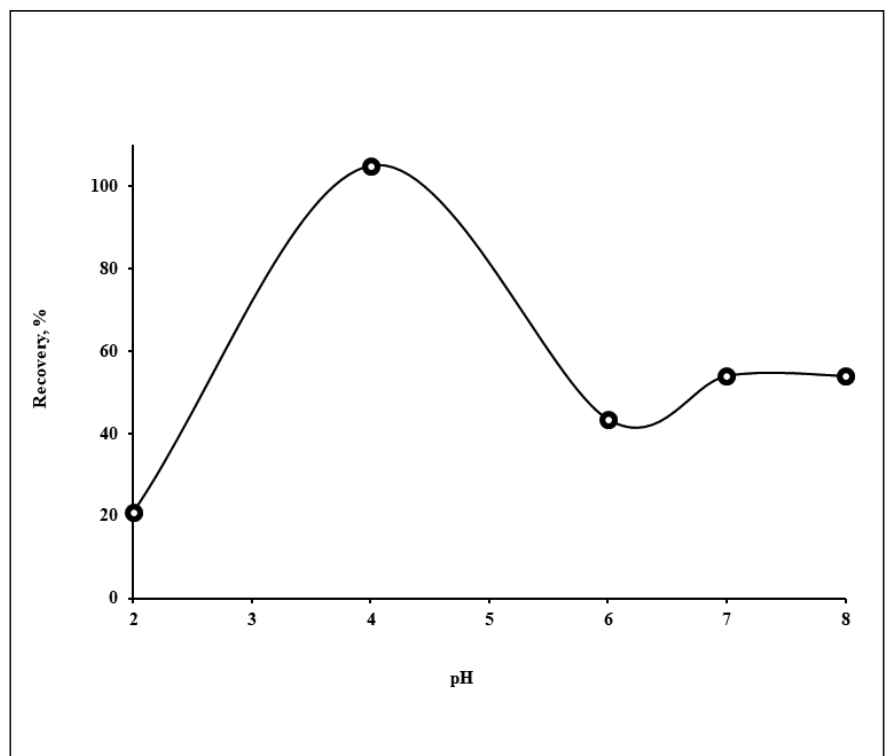

Fig. 1. Effects of $\mathrm{pH}$ on the recoveries of $\mathrm{Pb}(\mathrm{II})$.

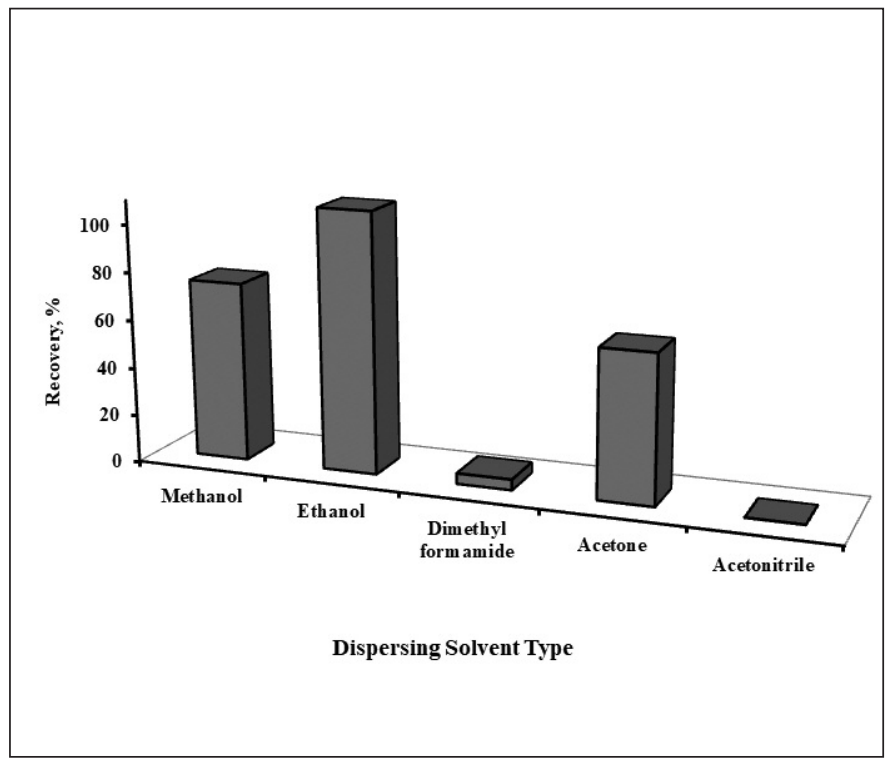

Fig. 3. The effects of different dispersing solvents on recoveries of $\mathrm{Pb}(\mathrm{II})$.

$\mathrm{Ca}^{2+}$, and $\mathrm{SO}_{4}^{-2}$ ). These results confirm that the proposed method is applicable to real samples in different matrices.

\section{Optimized Analytical Results}

The detection limits (LODs), quantification limits (LOQs), and the relative standard deviation (RSD) were calculated under the

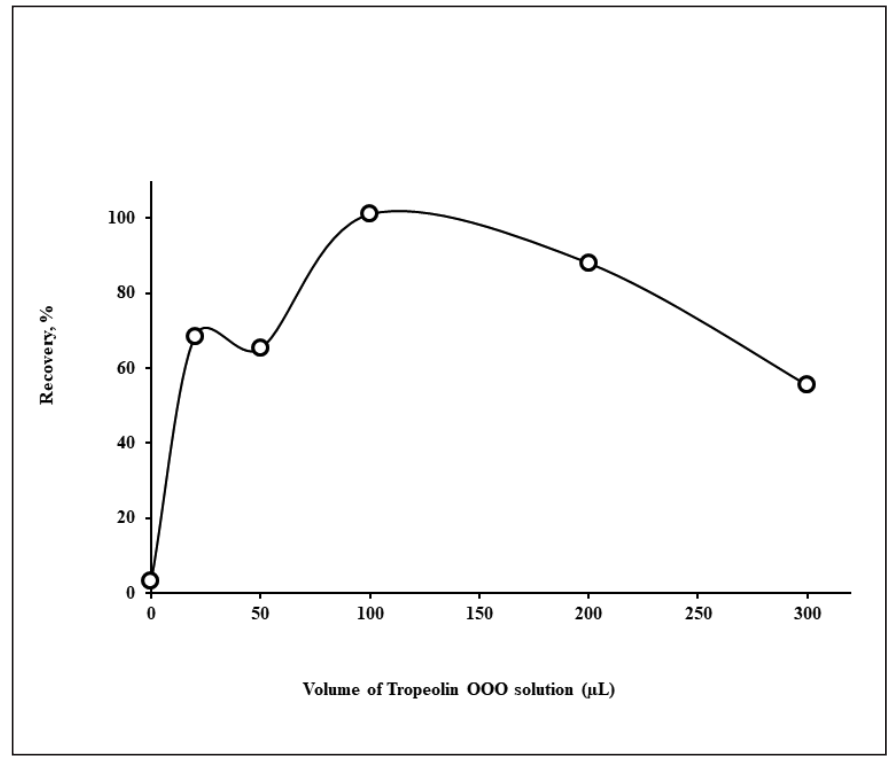

Fig. 2. The influence of volume of Tropaeolin OOO solution on the recoveries of $\mathrm{Pb}(\mathrm{II})$.

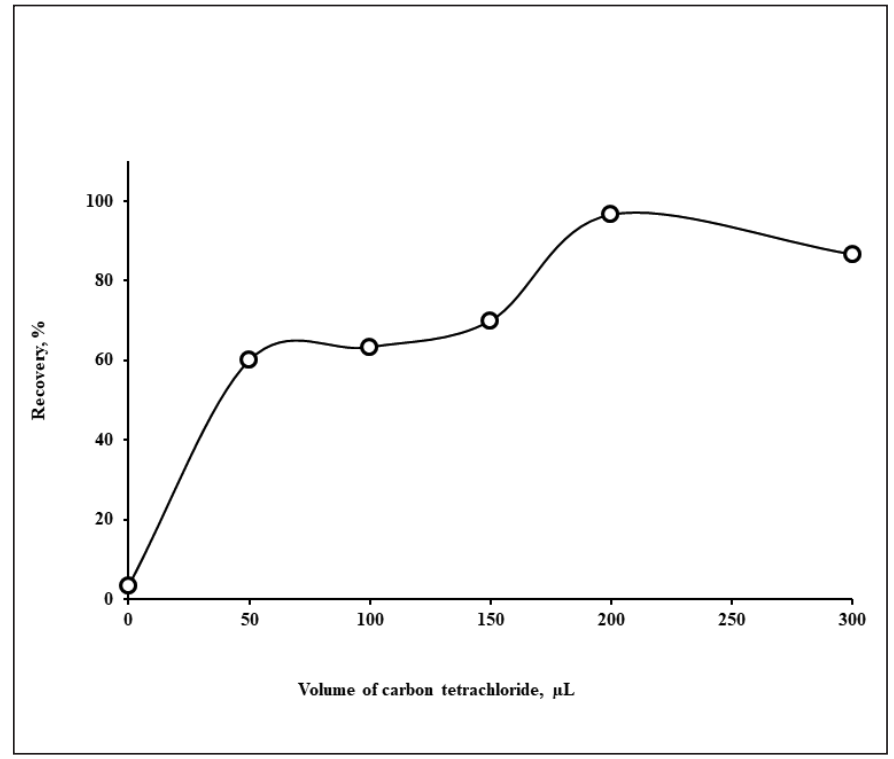

Fig. 4. The influences of the volume of carbon tetra chloride on the recoveries of PbII). optimized conditions and found to be $11.4 \mu \mathrm{g} \mathrm{L}^{-1}, 34.3 \mu \mathrm{g} \mathrm{L}^{-1}$, and $3.0 \%$, respectively.

For validation and accuracy of the proposed preconcentration method, different concentrations of $\mathrm{Pb}$ (II) were spiked into tap water during the extraction procedures, and the recovery (\%) was evaluated (see Table III). It can be seen that recovery of the spiked $\mathrm{Pb}$ (II) to real samples by the present microextraction procedure was in the quantitative range.

Furthermore, investigation of the proposed microextraction procedure for the standard reference materials and the CRMs TMDA 64.2 and TMDA 53.3 Fortified Water was performed, and the (\%) recovery 


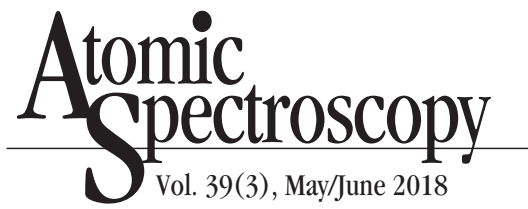

TABLE II

Recovery of $\mathrm{Pb}$ (II) Using Present Microextraction System in Presence of Various Coexisting Ions $(\mathrm{N}=3)$

\begin{tabular}{lclc}
\hline Ions & $\begin{array}{c}\text { Concentration } \\
(\mathrm{mg} / \mathrm{L})\end{array}$ & Added As & $\begin{array}{c}\text { Recovery } \\
(\%\end{array}$ \\
\hline $\mathrm{F}^{-}$ & 800 & $\mathrm{NaF}$ & $100 \pm 0.1$ \\
$\mathrm{Co}^{2+}$ & 5 & $\mathrm{Co}\left(\mathrm{NO}_{3}\right)_{2}$ & $98 \pm 1.6$ \\
$\mathrm{Ni}^{2+}$ & 10 & $\mathrm{Ni}\left(\mathrm{NO}_{3}\right)_{2} \cdot 6 \mathrm{H}_{2} \mathrm{O}$ & $105 \pm 0.6$ \\
$\mathrm{Cd}^{2+}$ & 10 & $\mathrm{Cd}\left(\mathrm{NO}_{3}\right)_{2} \cdot 6 \mathrm{H}_{2} \mathrm{O}$ & $116 \pm 0.9$ \\
$\mathrm{Fe}^{2+}$ & 10 & $\mathrm{Fe}\left(\mathrm{NO}_{3}\right)_{3} \cdot 9 \mathrm{H}_{2} \mathrm{O}$ & $89 \pm 0.3$ \\
$\mathrm{Zn}^{2+}$ & 10 & $\mathrm{Zn}\left(\mathrm{NO}_{3}\right)_{2}$ & $94 \pm 2.0$ \\
$\mathrm{Cu}^{2+}$ & 10 & $\mathrm{Cu}\left(\mathrm{NO}_{3}\right)_{2} \cdot 3 \mathrm{H}_{2} \mathrm{O}$ & $98 \pm 0.9$ \\
$\mathrm{~K}^{+} / \mathrm{Cl}^{-}$ & 1000 & $\mathrm{KCl}$ & $97 \pm 3.1$ \\
$\mathrm{Mg}^{2+}$ & 1500 & $\mathrm{Mg}\left(\mathrm{NO}_{3}\right)_{2} \cdot 6 \mathrm{H}_{2} \mathrm{O}$ & $97 \pm 0.2$ \\
$\mathrm{Ca}^{2+}$ & 1200 & $\mathrm{CaCl}$ & $95 \pm 1.9$ \\
$\mathrm{SO}_{4}{ }^{2-}$ & 400 & $\mathrm{Na}_{2} \mathrm{SO}_{4}$ & $102 \pm 2.8$ \\
\hline
\end{tabular}

TABLE V

Comparison of DLLME With Other Methods

for Separation-Preconcentration of Lead

\begin{tabular}{lllll}
\hline Method & $\begin{array}{c}\text { Detection } \\
\text { Limit }\left(\mu \mathrm{g} \mathrm{L}^{-1}\right)\end{array}$ & $\begin{array}{c}\text { Preconcentration } \\
\text { Factor }\end{array}$ & $\begin{array}{l}\text { RSD } \\
(\%)\end{array}$ & Ref. \\
\hline SPE & 8.4 & 260 & 1.4 & $(49)$ \\
SPE & 16 & 75 & $<10$ & $(50)$ \\
Coprecipitation & 16 & 250 & $2-3$ & $(51)$ \\
SPE & 22.5 & 27 & $\leq 9$ & $(52)$ \\
SPE & 10 & 50 & $<3$ & $(53)$ \\
CPE & 11 & 29.6 & 3.2 & $(54)$ \\
CPE & 7.5 & 25 & $<6.4$ & $(55)$ \\
MF & 31 & 150 & $<10$ & $(56)$ \\
LLE-UV-Vis & 12 & - & 1.8 & $(57)$ \\
DLLME & 11.4 & 30 & 3.0 & This study \\
\hline
\end{tabular}

SPE: Solid phase extraction.

CPE: Cloud point extraction.

MF: Membrane filtration.

LLE-UV-Vis: Liquid-liquid extraction-UV-Vis spectrophotometer.

DLLME: Dispersive liquid-liquid microextraction.

was calculated and compared with the certified values (Table IV). For this purpose, $3 \mathrm{~mL}$ each of TMDA 64.2 or TMDA 53.3 was taken into centrifuge tubes, brought to $15-\mathrm{mL}$ volume with distilled water, and the developed method applied. The lead concentrations were found to be equal to 57.2 and $69.8 \mu \mathrm{g} \mathrm{L}^{-1}$ in the $15-\mathrm{mL}$ sample solutions of TMDA 64.2 and TMDA 53.3 Fortified Water, with recoveries resulting in $99 \%$ and $98 \%$, respectively.
A comparison of the proposed method vs. previously reported separation-preconcentration methods are listed in Table V. It can be seen that superior performance with respect to the limits of detection, preconcentration factor, and relative standard deviation (with some exceptions) was generally achieved.

\section{Applications to Real Samples}

As has been reported, human exposure to $\mathrm{Pb}$ (II) is commonly
TABLE III

Addition/Recovery Investigations Pb(II) From Water Sample Using Proposed Microextraction System $(\mathbf{N}=3)$

\begin{tabular}{ccc}
\hline $\begin{array}{c}\text { Added } \\
(\mu \mathrm{g})\end{array}$ & $\begin{array}{c}\text { Found } \\
(\mu \mathrm{g})\end{array}$ & $\begin{array}{c}\text { Recovery } \\
(\%)\end{array}$ \\
\hline 0.0 & $\mathrm{UDL}^{\mathrm{a}}$ & - \\
2.0 & $2.0 \pm 0.3$ & 100 \\
4.0 & $3.9 \pm 0.2$ & 98 \\
\hline
\end{tabular}

${ }^{a}$ UDL: Under the detection limit.

TABLE IV

Validation of Proposed Microextraction Procedure Using Water CRMs ( $\mathrm{N}=3)$

CRMs Certified Found Recovery $\left(\mu \mathrm{g} \mathrm{L}^{-1}\right) \quad\left(\mu \mathrm{g} \mathrm{L}^{-1}\right) \quad(\%)$

TMDA

$\begin{array}{llll}64.2 & 286 & 284 \pm 18 \quad 99\end{array}$

TMDA

$53.3 \quad 349 \quad 341 \pm 15 \quad 98$

TABLE VI

Quantification of $\mathrm{Pb}$ (II) in Real Samples After Application of Proposed Microextraction Method $(\mathbf{N}=3)$

\begin{tabular}{lc}
\hline Samples & Concentrations \\
\hline Wastewater & $612 \pm 1 \mu \mathrm{g} \mathrm{L}^{-1}$ \\
River Water & $133 \pm 1 \mu \mathrm{g} \mathrm{L}^{-1}$ \\
Dam Water & $\mathrm{UDL}$ \\
Hair Sample & $54 \pm 1 \mu \mathrm{g} \mathrm{g}^{-1}$
\end{tabular}

Mean \pm standard deviation.

UDL: Under of the detection limit.

due to air, water, and food (38). Water systems such as the oceans, lakes, and rivers, air and dust particles, as well as industrial and urban activities are all contributors to lead pollution of the total enviornent (38-40).

In this study, in addition to different water samples, also human hair was analyzed as an indicator for lead pollution (41-43). Thus, monitoring of toxic metals existing in the environment is crucial for all life on earth (44-48). Table VI lists 
the levels of $\mathrm{Pb}$ (II) found in water and hair samples using the proposed microextraction system.

\section{CONCLUSION}

The proposed microextraction system is based on the quantitative extraction of $\mathrm{Pb}$ (II) using $1.0 \mathrm{~g}$ of Tropaeolin OOO chelates at $\mathrm{pH} 4$ with $200 \mu \mathrm{L}$ of $\mathrm{CCl}_{4}$. Different real water and hair samples were analyzed and the limit of detection achieved was found at $11.4 \mu \mathrm{g} \mathrm{L}^{-1}$. This procedure enhances the separation and isolation of $\mathrm{Pb}$ (II) and resulted in high recoveries (<95\%) from known spiked concentrations and reference materials. The method is effective in the presence of different matrixes.

\section{ACKNOWLEDGMENT}

The authors extend their sincere appreciation to the Deanship of Scientific Research at King Saud University for its funding this Research Group- RGP-043.

Received August 22, 2017.

\section{REFERENCES}

1. E. K. Silbergeld, Annu. Rev. Publ. Health 18,187 (1997).

2. J. Liu, D. Gao, Y. Chen, J. Jing, Q. Hu, and Y. Chen, Neurotoxicology 44, 1 (2014).

3. M. Dorpinghaus, A. Brieger, O. Panichkina, L. Rink, and H. Haase, J. Trace. Elem. Med. Bio. 37, 117 (2016).

4. S. Sobhanardakani, Pollution 3, 669 (2017).

5. G.E. El-Desoky, M.A.M. AboulSoud, Z.A. Al-Othman, M. Habila, and J.P. Giesy. Environ. Geochem. Health 36, 583 (2014).

6. M.A. Habila, Z.A. ALOthman, A.M. El-Toni, J.P. Labis, X. Li, F. Zhang, and M. Soylak, Microchim.
Acta 183, 2377-2384 (2016).

7. Z.A. ALOthman, M. Habila, E.Yilmaz, and M. Soylak, Microchim. Acta 177, 397 (2012).

8. Z.A. ALOthman, E. Yilmaz, M. Habila, and M. Soylak, Desalin. Water. Treat. 51, 6770 (2013).

9. Q. Zhou, N. Zhao, and G. Xie, J. Hazard. Mater. 189, 48 (2011).

10. M.J. Trujillo-Rodriguez, P. Rocio-Bautista, V. Pino, and A.M. Afonso, Trend. Anal. Chem. 51, 87 (2013).

11. Z.A. ALOthman, E. Yilmaz, M. Habila, A. Shabaka, and M. Soylak, Microchim. Acta 180, 669 (2013).

12. J.A. Baig, T.G. Kazi, L. Elci, H.I. Afridi, M.I. Khan, and H.M. Naseer, J. Anal. Methods Chem. 629495, 1 (2013).

13. I. Lopez-Garcia, Y. VicenteMartinez, and M. Hernandez-Cordoba, Talanta 110, 46 (2013).

14. I. Lopez-Garcia, Y. VicenteMartínez, and M. Hernández-Córdoba, Talanta 124, 106 (2014).

15. N. Jalbani, and M. Soylak, Talanta 131, 361 (2015).

16. E. Yilmaz, and M. Soylak, Talanta 116, 882 (2013).

17. E. Yilmaz, R.M. Alosmanov, and M. Soylak, RSC Adv. 5, 3380133808 (2015).

18. M. Soylak, and E. Yilmaz, Desalination 275, 297(2011).

19. S.R. Yousefi, and F. Shemirani, Anal. Chim. Acta 669, 25 (2010).

20. M. Habila, Z.A. ALOthman, and M. Soylak, Atom. Spectrosc. 36, 146 (2015).

21. M. Ezoddin, T. Taghizadeh, and B. Majidi, Environ. Technol. 35, 2401 (2014).

22. K. Shrivas, K. Dewangan, and A. Ahmed, Anal. Methods 8, 5519 (2016).

23. M.T. Naseri, M.R.M.

Hosseini, Y. Assadi, and A. Kiani, Talanta 75, 56 (2008).

24. V.A. Lemos, E.V.D. Vieira, E.D. Silva, and L.O. Dos Santos, Clean-Soil Air Water 40, 268 (2012).

25. A.M. Al-Othman, Z.A. ALOthman, G.E. El-Desoky, M.A.M. Aboul-Soud, M.A. Habila, and J.P. Giesy, Arab. J. Geosci. 6, 3103 (2013).

26. M. Habila, E. Yilmaz, Z.A. ALOthman, and M. Soylak, J. Ind. Eng. Chem. 20, 3989 (2014).

27. D. Ozdes, A. Gundogdu, B. Kemer, C. Duran, H.B. Senturk, and M. Soylak, J. Hazard. Mater. 166, 1480 (2009).

28. A.P. Santos, M.G.A. Korn, and V.A. Lemos, Environ. Monit. Assess. 189, 444 (2017).

29. M. Soylak, Y.E. Unsal, N. Kizil, and A. Aydin, Food Chem. Toxicol. 48, 517 (2010).

30. E. Ghasemi, and M. Kaykhaii, Eurasian J. Anal. Chem. 12, 313-324 (2017).

31. J.A. Baig, H.D. Memon, S.A.I. Bukhari, H.M. Naseer, L. Elci, J. AOAC Int. 100, 1062 (2017).

32. N.S. Kumar, V. Dharmendra, V. Sreenivasulu, M. Asif, A.A. Ibrahim, and V. Balaram, Metals 7 , 240 (2017).

33. E.K. Selvi, U. Sahin, and S. Sahan, Iran. J. Pharm. Res. 16, 1030 (2017).

34. S. Saracoglu, M. Soylak, and L. Elci, Talanta 59, 287 (2003).

35. C. Karadas, and D. Kara, Water Sci. Technol. 17, 1347 (2017).

36. M. Soylak, and L. Elci, J. Trace Microprobe T. 18, 397 (2000). 
37. M.S. Algamdi, A.S. Alghamdi, I.H. Alsohaimi, F.D. Allohybi, Alqadami, A.A., Desalin. Water Treat. 69, 261 (2017).

38. M. Soylak, L. Elci, and M. Dogan, J. Trace Microprobe T. 17, 149-156 (1999).

39. P. Grandjean, Hum. Toxicol. 3, 223 (1984).

40. A. Akdogan, U. Divrikli, M. Soylak, and L. Elci, Atom. Spectrosc. 37, 25 (2016).

41. E. Cetinkaya, and A. Aydin, Desalin. Water Treat. 74, 224 (2017).

42. H. Alijani, M.H. Beyki, Y. Fazli, and Z. Shariatini, Desalin. Water Treatmt. 66, 338 (2017).

43. V. Zarezade, A. Aliakbari, M. Es'haghi, M.M. Amini, M. Behbahani, F. Omidi, and G. Hesam, Int. J. Environ. Anal. Chem. 97, 383 (2017),

44. L. Shifera, K. Siraj, A. Yifru, Indian J. Chem. Techn. 24, 145 (2017).

45. E. Yilmaz, and M. Soylak, Turk. J. Chem. 40, 868 (2016).

46. N. Campillo, P. Viñas, J. Šandrejová, and V. Andruch, Appl. Spectrosc. Rev. 52, 267 (2017).

47. C. Canoluk and S.S. Gursoy, J. Macromol Sci. A, 54, 782 (2017)

48. M. Ghaedi, F. Ahmadi, Z. Tavakoli, M. Montazerozohori, A. Khanmohammadi, and $\mathrm{M}$. Soylak, J. Hazard. Mater. 152, 1248 (2008).

49. M. Ghaedi, F. Ahmadi, and A. Shokrollahi, J. Hazard. Mater. 142, 272 (2007).

50. I. Narin, Y. Surme, E. Bercin, and M. Soylak, J. Hazard. Mater. 145, 113 (2007).

51. G. Done, and A. Ege, Anal. Chim. Acta 547, 14 (2005).
52. W. Ngeontae, W. Aeungmaitrepirom, and $\mathrm{T}$. Tuntulani, Talanta 71, 1075 (2007).

53. Y.P. de Peña, M. Gallego, and M. Valcárcel, Talanta 42, 211 (1995).

54. N. Dallali, M.M. Zahedi, and Y. Yamini, Scientia Iranica 14), 291 (2007).

55. I. Narin, and M. Soylak, Anal. Chim. Acta 493, 205 (2003).

56. Y. Surme, I. Narin, M. Soylak, H. Yuruk, and M. Dogan, Microchim. Acta 157, 193 (2007).

57. A.L.D. Comitre, and B.F. Reis, Talanta 65, 846 (2005). 